\title{
In vitro growth of oocyte-granulosa cell complexes isolated from cryopreserved ovine tissue
}

\author{
H. Newton, H. Picton and R. G. Gosden \\ Centre for Reproduction, Growth and Development, D Floor, Clarendon Wing, Leeds General Infirmary, Leeds LS2 9NS, UK
}

\begin{abstract}
A culture system has been designed in which enzymatically isolated oocyte-granulosa cell complexes from fresh and frozen-thawed ovine ovarian tissue can be grown to antral size in vitro. Oocyte-granulosa complexes ranging from 100 to $240 \mu \mathrm{m}$ in diameter were dissected from stromal tissue and grown individually in serum-free medium for 30 days. Complexes $<190 \mu \mathrm{m}$ generally excluded their oocytes or lost three-dimensional structure early in the culture period. In contrast, complexes isolated from fresh or frozen-thawed tissue and measuring 190-240 $\mu \mathrm{m}$ on the day of isolation formed antral cavities in $25 \pm 9 \%$ and $18 \pm 6 \%$ (mean \pm SEM) of cases, respectively. The effect of gonadotrophin supplementation to the culture medium was tested on frozen-thawed oocyte-granulosa cell complexes only. In cultures supplemented with both FSH and LH or FSH alone, there was no significant difference in the number of oocyte-granulosa cell complexes that formed antral cavities $(18 \pm 7 \%)$. However, antrum formation was significantly less frequent in cultures lacking gonadotrophin stimulation $(7 \pm 4 \%)$. All oocyte-granulosa cell complexes maintained a threedimensional structure throughout culture and developed a functional P450 aromatase enzyme complex, as revealed by the induction of oestradiol production during 8 days of culture after antrum formation in serum-free medium containing testosterone. Oocytes recovered after 30 days of culture were viable and had increased in diameter from $78 \pm 2 \mu \mathrm{m}$ on the day of isolation, to $131 \pm 3 \mu \mathrm{m}$ at the end of culture. These results show that oocyte-granulosa cell complexes isolated from cryopreserved ovarian tissue can be grown to antral size in vitro with similar efficiency to those isolated from fresh tissue.
\end{abstract}

\section{Introduction}

Cryopreservation of ovarian tissue is a new and promising technique for preserving fecundity which may be applicable to cancer patients who are at risk of sterilization from chemotherapy or radiotherapy treatment, or for safeguarding the reproductive potential of endangered species (Oktay et al., 1998). Laparoscopic techniques facilitate the recovery of ovarian cortical biopsies that contain hundreds or even thousands of follicles. The histological examination of human ovarian tissue after freeze-thawing indicates the presence of morphologically normal follicles (Hovatta et al., 1996) and quantification of the number of follicles after xenografting samples into immunodeficient mice for 18 days shows that $44-84 \%$ of the population survives (Newton et al., 1996). Although freeze-banking ovarian tissue preserves a substantial proportion of the follicle store, no suitable method is available for harvesting the reproductive potential from this material.

One option is to isolate immature follicles from the surrounding stroma for growth to maturity in vitro (Gosden et al., 1993; Hartshorne, 1997). Dissection of ovarian cortical

Received 27 May 1998. tissue harvests a large number of follicles, many of which are naturally destined to undergo atresia without ovulating. Murine tissue can be teased apart with fine needles to yield preantral follicles that can be grown to maturity in vitro even if the isolated follicles are frozen-thawed before culture (Qvist et al., 1990; Nayudu and Osborn, 1992; Cortvrindt et al., 1996a,b). Oocytes ovulated from the cultured follicles in response to LH have been fertilized and produced blastocysts which, after transfer to pseudopregnant females, resulted in the birth of viable pups (Spears et al., 1994).

The success of in vitro follicle culture techniques is dependent on the ability to harvest efficiently large numbers of healthy preantral follicles from ovarian tissue. Although manual dissection has proved successful in mice, the technique is laborious, time consuming and difficult in species with a fibrous stroma such as humans and ruminants. Enzymatic isolation with collagenase is more efficient, but this procedure removes the thecal layer and damages the basement membrane, thus isolating oocytegranulosa cell complexes rather than intact follicles (Hirao et al., 1994; Li et al., 1995; Hartshorne, 1997). Nevertheless, human, pig, rat and hamster oocyte-granulosa cell complexes isolated in this manner form antral cavities in culture (Roy and Greenwald, 1989; Roy and Treacy, 1993; 
Hirao et al., 1994; Cain et al., 1995; Li et al., 1995; Abir et al., 1997).

The aim of this study was to investigate the in vitro growth and developmental potential of oocyte-granulosa cell complexes enzymatically harvested from frozen-thawed ovine ovarian tissue. The sheep ovary was chosen as an experimental model because it is similar in consistency to the human ovary, with a dense fibrous stroma. In addition, ovine follicles have a growth phase of similar duration to that of human follicles. The successful development of an in vitro growth system for human follicle culture may allow mature oocytes to be harvested from the banked ovarian tissue of cancer patients. The technology would also facilitate assisted conception programmes, allowing the collection of mature oocytes from small ovarian biopsies without the need for costly and potentially harmful controlled ovarian stimulation and follicular aspiration. Furthermore, the procedures may be valuable in the reproductive management of transgenic animals, rare breeds and endangered species.

\section{Materials and Methods}

\section{Collection of tissue}

Prepubertal sheep ovaries were collected from a local abattoir and placed in Leibovitz L-15 medium on ice for transport to the laboratory within $1 \mathrm{~h}$ of collection. The ovaries were washed in fresh medium at room temperature $\left(20^{\circ} \mathrm{C}\right)$ and briefly rinsed with $70 \%(\mathrm{v} / \mathrm{v})$ ethanol before being transferred to fresh Leibovitz L-15 medium supplemented with $100 \mathrm{iu}$ penicillin $\mathrm{ml}^{-1}$ and $40 \mathrm{iu}$ streptomycin sulphate $\mathrm{ml}^{-1}$. This solution is referred to as antibiotic medium. Individual ovaries were placed in a large sterile Petri dish and the outer $1 \mathrm{~mm}$ cortical tissue was removed with a scalpel and cut into squares of $0.5 \mathrm{~cm} \times 0.5 \mathrm{~cm}$. Unless otherwise stated, all media and culture reagents were obtained from Sigma Chemical Co. Ltd (Poole).

\section{Cryopreservation}

Dimethyl sulphoxide (DMSO) was prepared at a concentration of $1.5 \mathrm{~mol} \mathrm{l}^{-1}$ in Leibovitz medium supplemented with $10 \%(\mathrm{v} / \mathrm{v})$ heat inactivated fetal calf serum (FCS) and $0.1 \mathrm{~mol}$ sucrose $\mathrm{l}^{-1}$. The cryoprotectant solution $(1.5 \mathrm{ml})$ was aliquotted into $1.8 \mathrm{ml}$ cryovials (Nunclon, Life Technologies, Paisley) and $40 \mathrm{ml}$ was transferred into a $50 \mathrm{ml}$ conical tube (Falcon, Becton Dickinson, NJ). The ovarian pieces were moved into the conical tube and gently rolled $(1 \mathrm{~Hz})$ on a Spiramix at $4^{\circ} \mathrm{C}$ for $30 \mathrm{~min}$ to allow equilibration of the cryoprotective agent. The contents of the conical tube were poured into a large sterile Petri dish and four pieces of ovarian cortex were placed into each cryovial. The vials were cooled in a programmable freezer (Kryo 10, Planar Instruments, Middlesex) as follows: (i) cooled from $0^{\circ} \mathrm{C}$ at $2^{\circ} \mathrm{C}$ per min to $-9^{\circ} \mathrm{C}$; (ii) seeded manually; (iii) cooled at $0.3^{\circ} \mathrm{C}$ per min to $-40^{\circ} \mathrm{C}$; (iv) cooled to $-140^{\circ} \mathrm{C}$ at $10^{\circ} \mathrm{C}$ per min; (v) plunged into liquid nitrogen and stored in a Dewar tank for up to 3 months (Gosden et al.,
1994). The vials were thawed rapidly by agitating in a waterbath at room temperature for approximately $30 \mathrm{~s}$ and the tissue was washed for approximately $10 \mathrm{~min}$ in two changes of fresh Leibovitz medium to remove cryoprotective agent. Samples of unfrozen ovarian cortex from randomly selected ovaries were prepared as described above to act as controls to compare the effects of cryopreservation on oocyte-granulosa cell complex development in vitro.

\section{Isolation of oocyte-granulosa cell complexes}

The wet weight of frozen-thawed or fresh ovarian cortex was recorded before the tissue was finely minced with a scalpel and transferred to a culture flask containing prewarmed Leibovitz medium supplemented with $1 \mathrm{mg}$ collagenase $1 \mathrm{~A} \mathrm{ml}^{-1}\left(432 \mathrm{U} \mathrm{mg}^{-1}\right), 8 \mathrm{kU}^{-}$Nase $\mathrm{ml}^{-1}$ and $10 \%$ $(\mathrm{v} / \mathrm{v}) \mathrm{FCS}$. The tissue was incubated for $1 \mathrm{~h}$ at $37^{\circ} \mathrm{C}$ with gentle rocking to aid digestion. The tissue was then removed from the digestion medium and washed twice in antibiotic medium containing $10 \%(\mathrm{v} / \mathrm{v}) \mathrm{FCS}$ at $37^{\circ} \mathrm{C}$. Oocyte-granulosa cell complexes ranging from 100 to $240 \mu \mathrm{m}$ in diameter were isolated using 27 gauge insulin needles (Terumo Europe, Leuven) under a dissecting microscope $(\times 240)$. Dissection was carried out at room temperature and under sterile conditions. The approximate time taken to isolate oocyte-granulosa cell complexes from $1 \mathrm{~g}$ digested tissue was $3 \mathrm{~h}$. Isolated complexes were transferred using a $200 \mu$ l Gilson pipette into fresh antibiotic medium containing $10 \%(\mathrm{v} / \mathrm{v}) \mathrm{FCS}$ and held at $37^{\circ} \mathrm{C}$ until culture. Morphology was assessed under a dissecting microscope $(\times 240)$ before the start of culture and only those samples with an intact round structure and a spherical centrally located oocyte were used in the study.

\section{Oocyte-granulosa cell complex culture}

Oocyte-granulosa cell complexes were cultured individually in 96-well sterile flat-bottomed plates (Nunclon, Life Technologies, Paisley) at $37^{\circ} \mathrm{C}$ under an atmosphere of $5 \% \mathrm{CO}_{2}$ and $95 \%$ air. Cultures were grown in $200 \mu 1$ serumfree medium that had been optimized for the induction of aromatase activity and oestradiol production in isolated sheep granulosa cell cultures (Campbell et al., 1996). The serum-free culture medium consisted of $\alpha$ minimal essential medium (Life Technologies, Paisley) supplemented with $0.1 \%\left(\mathrm{w} / \mathrm{v}\right.$ ) BSA (cell culture grade), $100 \mathrm{iu}$ penicillin $\mathrm{ml}^{-1}$, $40 \mathrm{iu}$ streptomycin $\mathrm{ml}^{-1}, 5 \mathrm{\mu g}$ bovine holo-transferrin $\mathrm{ml}^{-1}$, $3.8 \mu$ g pyruvic acid $\mathrm{ml}^{-1}, 5 \mathrm{ng}$ sodium selenite $\mathrm{ml}^{-1}, 3 \mathrm{mmol} \mathrm{L-}$ glutamine $\mathrm{I}^{-1}, 10 \mathrm{ng}$ bovine insulin $\mathrm{ml}^{-1}$ and $10 \mathrm{ng}$ long R3 insulin-like growth factor $\mathrm{I} \mathrm{ml}^{-1}$ (LR3-IGF-I; media grade, Gropep Pty Ltd, Adelaide). This basic culture medium was supplemented with ovine FSH (NIADDK-oFSH-17; bioactivity $20 \mathrm{iu} \mathrm{mg}{ }^{-1}$ ) at a concentration of $0.5 \mathrm{ng} \mathrm{ml}^{-1}$ and ovine LH (NIADDK-oLH-26; bioactivity $2.3 \mathrm{iu} \mathrm{mg}^{-1}$ ) at a concentration of $0.1 \mathrm{ng} \mathrm{ml}^{-1}$. Three combinations of gonadotrophin supplementation were evaluated in the serum-free culture. Follicles received either no hormonal supplements, FSH. supplementation, or supplementation with both FSH and LH. 
For comparative purposes, individual oocyte-granulosa cell complexes were also cultured in $\alpha$ minimal essential medium containing antibiotics, sodium selenite, transferrin and pyruvate as detailed above and supplemented with 5\% $(\mathrm{v} / \mathrm{v})$ donor calf serum and $5 \mu \mathrm{g}$ bovine insulin $\mathrm{ml}^{-1}$. Serumcontaining medium was prepared with $0.5 \mathrm{ng}$ ovine FSH $\mathrm{ml}^{-1}$ and $0.1 \mathrm{ng}$ ovine LH ml${ }^{-1}$ (from the same batch as the serum-free cultures).

The period of in vitro growth was 30 days and each experimental group represents the data collected from 55-57 oocyte-granulosa cell complexes accumulated during 12 cultures carried out on different days. At $48 \mathrm{~h}$ intervals, $100 \mu \mathrm{l}$ culture medium was removed and replenished with fresh medium. Spent samples were stored at $-20^{\circ} \mathrm{C}$ for oestradiol and progesterone assays. Both complex diameter and oocyte diameter were recorded on day 0 of culture using an inverted microscope with Hoffman optics $(\times 100$ and $\times 400$ ) (Nikon, Japan). Subsequent measurements were made before each change of medium.

\section{Histology}

Oocyte-granulosa cell complexes isolated on day $0(n=8)$ and complexes that had formed an antral cavity during 30 days of culture in serum-free media without hormonal supplements or with FSH $(n=7)$ were fixed in Bouin's solution overnight at room temperature. The specimens were dehydrated through increasing concentrations of ethanol before they were embedded in wax. The samples were sectioned at $5 \mu \mathrm{m}$ and stained with haematoxylin and eosin or Heidenhains Azan stain for the collagen component of the basement membrane (Culling, 1974). Four pieces of fresh ovarian cortex were fixed and histologically prepared to act as control tissue for the Azan stain. Very few oocytegranulosa cell complexes cultured in serum-free media without gonadotrophin stimulation formed antral cavities, thus these samples were excluded from the studies of histology, DNA content and steroid production.

\section{DNA analysis}

Oocyte-granulosa cell complexes isolated on day $0(n=10)$ or complexes that formed an antral cavity during 30 days of culture in serum-free media supplemented with FSH and LH or FSH alone $(n=10)$ were suspended in $10 \mu$ sterile sodium citrate (SSC) ( 0.15 mol sodium chloride $\mathrm{l}^{-1}, 0.015 \mathrm{~mol}$ sodium citrate $\mathrm{l}^{-1}, \mathrm{pH} 7$ ) containing $0.02 \%(\mathrm{w} / \mathrm{v})$ lauryl sulphate (SDS) and stored in $0.5 \mathrm{ml}$ Eppendorf tubes at $-20^{\circ} \mathrm{C}$. Samples were thawed on the day of DNA analysis. SSC/SDS solution was added $(40 \mu \mathrm{l})$ to each tube and the samples were incubated for $75 \mathrm{~min}$ at $37^{\circ} \mathrm{C}$ with occasional agitation to lyse the cells. The tubes were then sonicated briefly and centrifuged at $400 \mathrm{~g}$ for $12 \mathrm{~min}$. Samples $(25 \mu \mathrm{l})$ were transferred to black flatbottomed 96-well microplates (Dynatech Laboratories Ltd, Billinghurst) and the amount of DNA present was measured with a bis-benzamide fluorescent assay on a fluorolite 1000 plate reader according to manufacturer's recommendations (Dynatech Laboratories Ltd, Billinghurst). DNA concentrations were measured against a standard curve of calf thymus DNA (10 $\mu$ l per well) with concentrations ranging from 40 to $8000 \mathrm{ng}$ per $10 \mu \mathrm{l}$. The lower limit of sensitivity of the assay was $5 \mathrm{ng}$ DNA per $10 \mu \mathrm{l}$.

\section{Steroid measurements}

Oestradiol. For the 8 days after antrum formation, oocyte-granulosa cell complexes were cultured in media containing $100 \mathrm{ng}$ testosterone $\mathrm{ml}^{-1}(n=12)$. Spent medium recovered at $48 \mathrm{~h}$ intervals was assayed for oestradiol content by ELISA (Ridgeway Science Ltd, Gloucester) using a spectrophotometer at $450 \mathrm{~nm}$ (MRX, Dynatech Laboratories Ltd, Billinghurst). Spent medium was collected over the same time period from complexes with an antral cavity that were cultured in serum-free medium without testosterone supplementation $(n=5)$ to act as a control. Samples were measured in two assays against a standard curve with values ranging from 0.05 to $5.0 \mathrm{ng} \mathrm{ml}^{-1}$. The limit of detection of the assay was $0.02 \mathrm{ng} \mathrm{ml}^{-1}$. The intra- and interassay coefficients of variation were 10.2 and $13.0 \%$, respectively.

Progesterone. Spent medium recovered at $48 \mathrm{~h}$ intervals was also assayed for progesterone content by ELISA (Ridgeway Science Ltd, Gloucester) using a spectrophotometer at $540 \mathrm{~nm}$ (MRX, Dynatech Laboratories Ltd, Billinghurst). All samples were measured in one assay against a standard curve with values ranging from 0.2 to $20 \mathrm{ng} \mathrm{ml}^{-1}$. The limit of detection of the assay was $0.2 \mathrm{ng} \mathrm{ml}^{-1}$ and the intra-assay coefficient of variation was $8.2 \%$. Both oestradiol and progesterone measurements at each $48 \mathrm{~h}$ time point were adjusted to allow for the carry-over effect before analysis (Campbell et al., 1996).

\section{Oocyte viability assay}

At the end of culture, oocyte-cumulus complexes that had formed an antral cavity during 30 days of culture in serumfree media with FSH and LH or FSH alone $(n=10)$ were transferred to a Petri dish and gently teased apart using two 27 gauge insulin needles. The oocytes were retrieved and their diameters measured under an inverted microscope (Diaphot, Nikon, Japan). The viability of the oocytes was assessed by incubation in 5 (and 6)-carboxyfluorescein diacetate succinimidyl ester (CFSE; Molecular Probes Inc., Cambridge Bioscience, Cambridge) at a concentration of $50 \mu \mathrm{g} \mathrm{ml}^{-1}$ at $37^{\circ} \mathrm{C}$ for $30 \mathrm{~min}$ (Oktay et al., 1997). The oocytes were washed briefly in PBS and mounted onto glass slides for examination under the fluorescence microscope at $\times 250$ magnification (6007 series, Wang Bio Medical, Wageningen). Viable cells fluoresce green at $570 \mathrm{~nm}$.

\section{Statistical analysis}

The data were analysed with the Student's $t$ test and analysis of variance (ANOVA). Steroid data were log transformed before analysis. All values presented are mean \pm SEM. 
(a)
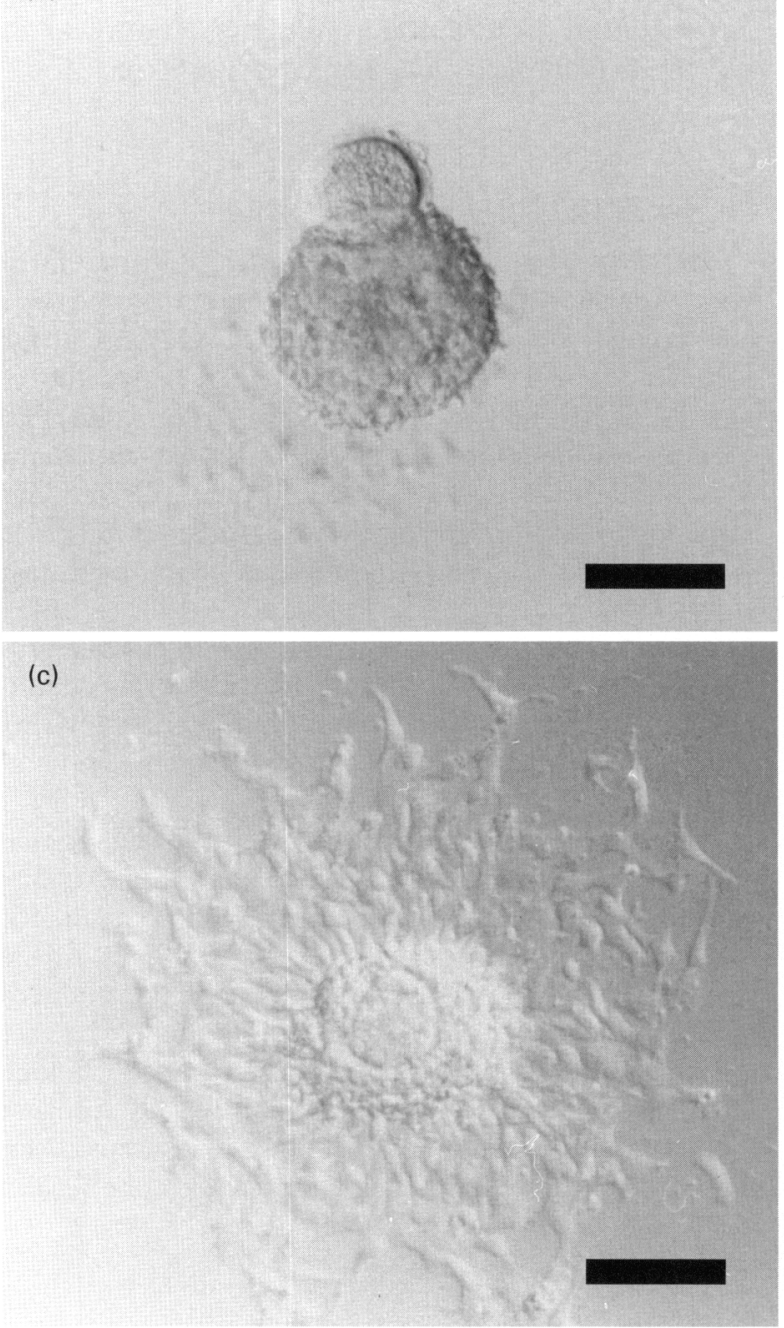

(b)
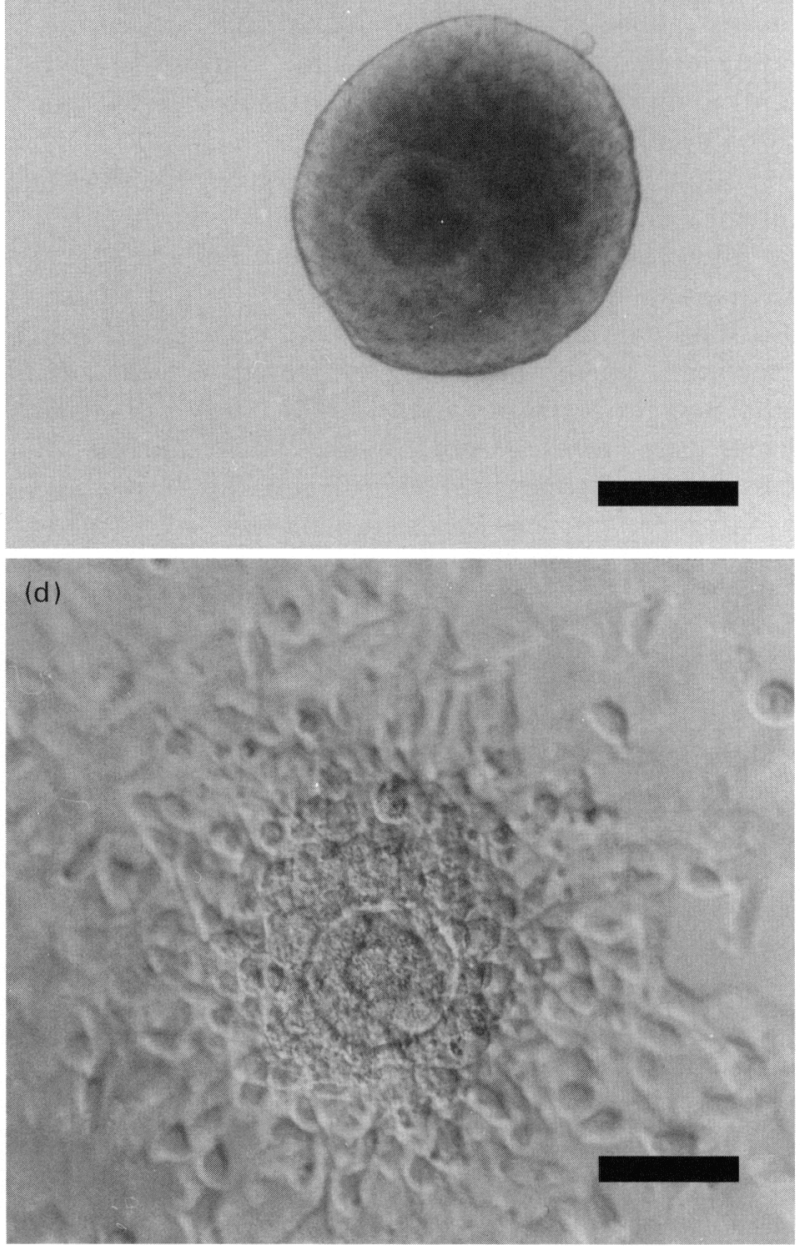

Fig. 1. Appearance of damaged oocyte-granulosa cell complexes after isolation from fresh or frozen-thawed ovine tissue and culture for $120 \mathrm{~h}$. Approximately $60 \%$ of complexes (a) extruded their oocyte, (b) had a necrotic oocyte, or (c,d) lost threedimensional spherical structure and collapsed onto the culture plate. Scale bars represent $85 \mu \mathrm{m}$.

\section{Results}

The fibrous nature of the ovarian tissue was significantly reduced after $1 \mathrm{~h}$ of collagenase digestion, and oocytegranulosa cell complexes measuring between 100 and $240 \mu \mathrm{m}$ in diameter were easily isolated. Histological examination of samples of ovine cortical tissue indicated that follicles $>240$ $\mu \mathrm{m}$ in diameter had started to form small antral spaces. Oocyte-granulosa cell complexes of this size were therefore excluded from all culture experiments.

All oocyte-granulosa cell complexes measuring $<190 \mu \mathrm{m}$ in diameter and $58.7 \pm 5.3 \%$ of complexes measuring $190-240$ $\mu \mathrm{m}$ showed signs of damage after $120 \mathrm{~h}$ of in vitro culture. Morphological changes observed included the extrusion of the oocyte from the complex (Fig. 1a), the appearance of dark necrotic areas (Fig. 1b), and the 'collapse' of the complex resulting in a loss of spherical structure, spreading and adherence of the granulosa cells to the bottom of the culture well (Fig. 1c,d). The proportion of oocyte-granulosa cell complexes exhibiting the latter anomaly increased when the duration of collagenase digestion was extended from 60 to $105 \mathrm{~min}$ (H. Newton, unpublished observations). Since no oocyte-granulosa cell complexes $<190 \mu \mathrm{m}$ in diameter survived $120 \mathrm{~h}$ of culture, all the results discussed hereafter refer to follicles in the range $190-240 \mu \mathrm{m}$ on the day of isolation.

Oocyte-granulosa cell complexes measuring 190-240 $\mu \mathrm{m}$ in diameter on the day of isolation frequently adhered to the bottom of the culture well by elongated cellular extensions from the complex that lay on a 'mat' of cells. The number of morphologically normal oocyte-granulosa cell complexes of this size harvested from $1 \mathrm{~g}$ (wet weight) fresh and frozenthawed tissue was $15.0 \pm 3.8$ and $10.3 \pm 1.6$, respectively. Fewer frozen-thawed complexes were considered morphologically normal because they had signs of necrosis at the time of isolation; similar observations were not recorded in complexes isolated from fresh tissue.

Many morphologically normal oocyte-granulosa cell 

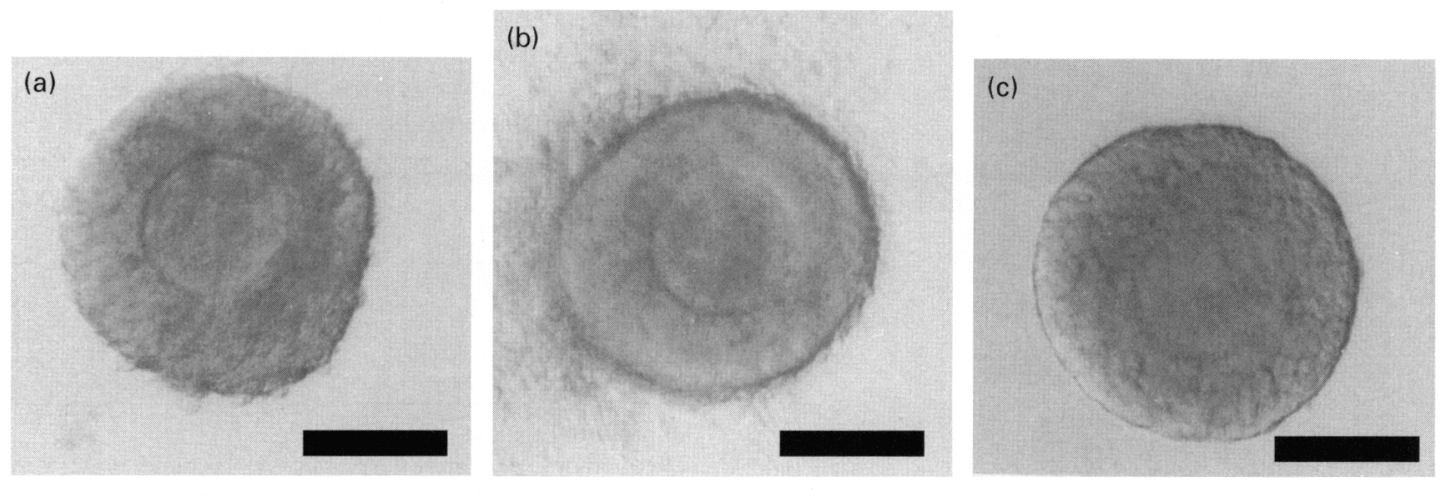

(d)

Fig. 2. (a-c) Oocyte-granulosa cell complexes isolated from frozen-thawed ovine tissue on day 0 of culture. (d) Oocyte-granulosa cell complex with an antral cavity formed during 30 days of culture in serum-free medium, showing how the complex maintained a three-dimensional spherical structure. Scale bars represent $85 \mu \mathrm{m}$.

complexes (Fig. 2a-c) grown for 30 days in serum-free culture formed antral cavities and maintained a spherical or semi-spherical (with a flattened surface at the point of contact with the plate) three-dimensional structure during growth and expansion (Fig. 2d). Complexes that were cultured in medium containing $5 \%$ serum rarely maintained a three-dimensional structure. In the presence of serum, follicular cells adhered to the culture surface, proliferated and tended to form flattened monolayers, with a collapsed appearance similar to that observed earlier (Fig. 1c,d).

Antrum formation was observed in $25 \pm 9 \%$ and $18 \pm 6 \%$ of the initial population of oocyte-granulosa complexes grown in serum-free medium supplemented with FSH and LH after isolation from fresh and frozen-thawed tissue, 

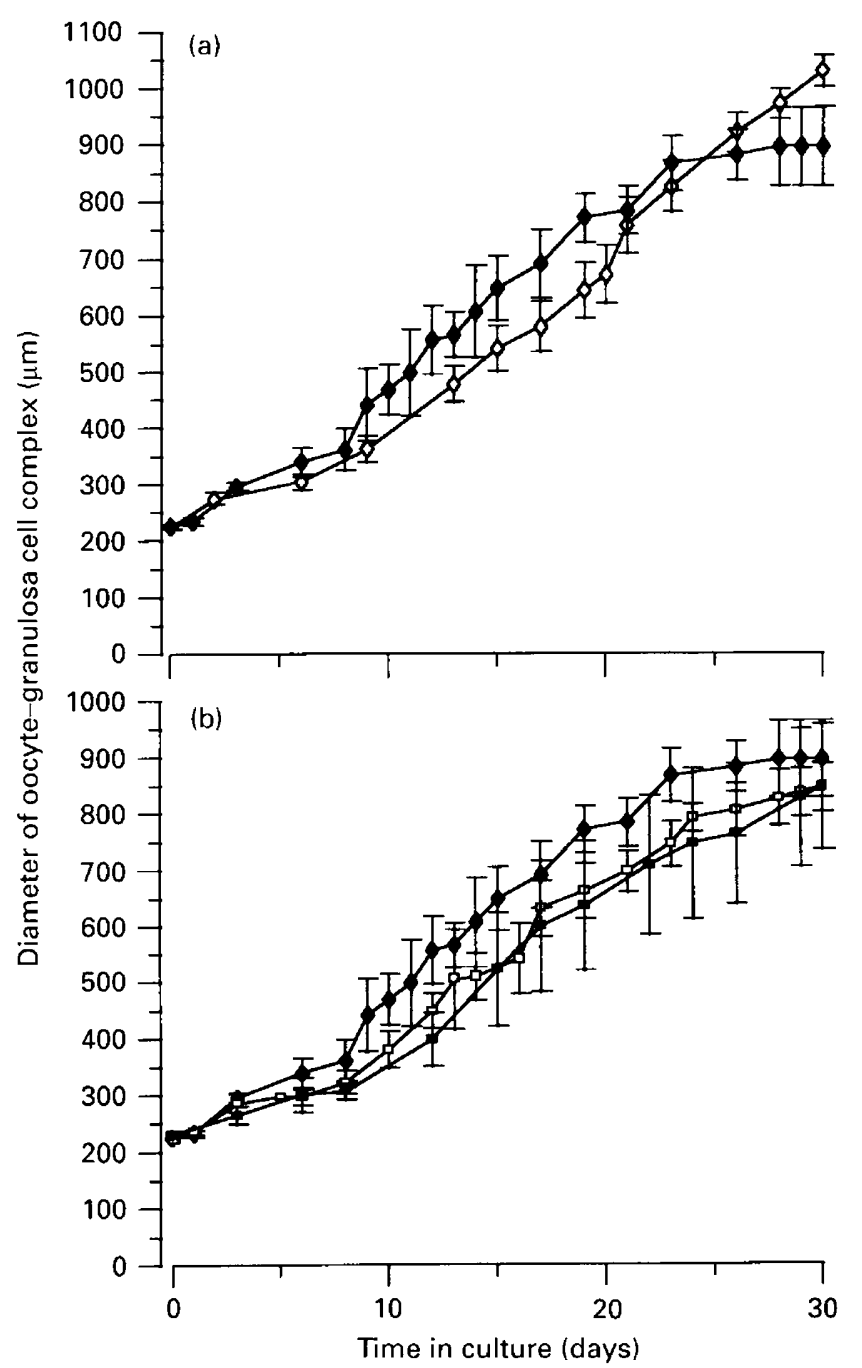

Fig. 3. Growth rate of oocyte-granulosa cell complexes after isolation from ovine tissue during culture for 30 days in serum-free medium. (a) Complexes isolated from $(\diamond)$ fresh and $(\diamond)$ frozen-thawed tissue $(n=9-11)$. (b) Complexes isolated from frozen-thawed tissue grown to maturity in medium $(\square)$ without gonadotrophins $(n=4)$ or supplemented with $(\square)$ FSH $(n=10)$ or $(\checkmark) \mathrm{FSH}$ and LH $(n=9)$. The diameter of the oocyte-granulosa cell complexes increased significantly in all groups during 30 days in culture $(P<0.001)$. Data points represent means \pm SEM.

respectively. Antral cavities were observed in the two groups after $13.8 \pm 0.8$ and $12.0 \pm 1.6$ days of in vitro culture, respectively. There was no significant difference in these means or in the subsequent rate of growth and expansion ( $\mu \mathrm{m}$ per day) of fresh and frozen-thawed oocyte-granulosa cell complexes (Fig. 3a). After 30 days in culture, the final diameter of complexes isolated from fresh tissue was significantly greater than those isolated from frozen-thawed tissue $(1027 \pm 26 \mu \mathrm{m}$ versus $882 \pm 56 \mu \mathrm{m} ; P<0.002)$.

Oocyte-granulosa cell complexes isolated from frozenthawed ovine tissue were used to investigate the effect of different gonadotrophic environments on growth. In serumfree medium supplemented with either FSH and LH or FSH alone, $18 \%$ of frozen-thawed complexes formed antral cavities; this value decreased to $7 \%$ with no gonadotrophin
Table 1. Development of oocyte-granulosa cell complexes measuring $190-240 \mu \mathrm{m}$ in diameter on the day of isolation from frozen-thawed ovine tissue during 30 days of culture in serum-free media with or without gonadotrophins

\begin{tabular}{lcc}
\hline Treatment & $\begin{array}{c}\text { Percentage antral } \\
\text { cavity formation }\end{array}$ & $\begin{array}{c}\text { Day of antrum } \\
\text { formation }\end{array}$ \\
\hline FSH + LH & $18.0 \pm 6.0^{\mathrm{a}}$ & $12.0 \pm 1.6^{\mathrm{a}}$ \\
FSH & $18.0 \pm 12.0^{\mathrm{a}}$ & $14.7 \pm 1.2^{\mathrm{a}}$ \\
Control & $7.0 \pm 4.0^{\mathrm{b}}$ & $15.5 \pm 2.0^{\mathrm{a}}$ \\
\hline
\end{tabular}

Values are means \pm SEM

The columns of data show the percentage of complexes that formed antral cavities $(n=55-57)$ and the mean day of antrum formation $(n=4-11)$. Within columns, values with different letters are significantly different $(P=0.02)$.

stimulation (Table 1, $P=0.02$ ). The gonadotrophic environment had no effect on the day of antrum formation or on the rate of growth and expansion of the oocyte-granulosa cell complexes (Fig. 3b). The diameter of oocyte-granulosa cell complexes in all groups increased significantly during 30 days of in vitro growth $(P<0.001)$.

Measurements of the DNA content of the oocytegranulosa cell complexes showed a mean increase from $177 \pm 7 \mathrm{ng}$ per complex on the day of isolation to $1124 \pm 63$ ng per complex after 30 days in culture $(P<0.001)$ (Fig. 4 a). Oocyte diameter increased from $78 \pm 2 \mu \mathrm{m}$ to $131 \pm 3 \mu \mathrm{m}$ with a zona thickness of $12 \pm 1 \mu \mathrm{m}(P<0.001)$ (Fig. 4b). All oocytes appeared morphologically normal at the end of culture and those tested $(n=10)$ were found to be viable, as indicated by CFSE staining.

Histological examination of whole sheep ovaries stained by the Azan method revealed blue staining where collagen was expected (thecal layer) with red counterstaining of nuclei and fibrin (Fig. 5a,b). In contrast, oocyte-granulosa cell complexes grown in vitro to the antral stage showed no positive staining for collagen (Fig. $5 c, d$ ). Morphological differences were also observed in the follicular granulosa cell populations of the ovarian sections and cultured follicles. In vivo, antral follicles appeared to have two distinct cell populations: a large population of spherical granulosa cells adjacent to the antral cavity and surrounding the oocyte and columnar mural granulosa cells adjacent to the basal lamina. In contrast, oocyte-granulosa cell complexes that formed antral cavities in vitro had only the spherical cell population.

Oestradiol concentrations were measured in spent medium collected every $48 \mathrm{~h}$ during an 8 day incubation of the oocyte-granulosa cell complexes with antral cavities in serum-free media supplemented with testosterone (Fig. 6). No significant difference was recorded between (i) groups of complexes isolated from fresh or frozen-thawed tissue, (ii) frozen-thawed complexes grown in medium supplemented with FSH and LH or FSH alone, or (iii) oestradiol production measured after each $48 \mathrm{~h}$ time point. The data were pooled to give a mean oestradiol production of $2.4 \pm 0.4 \mathrm{ng}$ per ml per $48 \mathrm{~h}$. These results indicate that the aromatase enzyme complex was induced in the cultured cells. Mean oestradiol concentrations measured in control samples collected from oocyte-granulosa cell complexes with antral cavities cultured for 8 days in media without testosterone were 


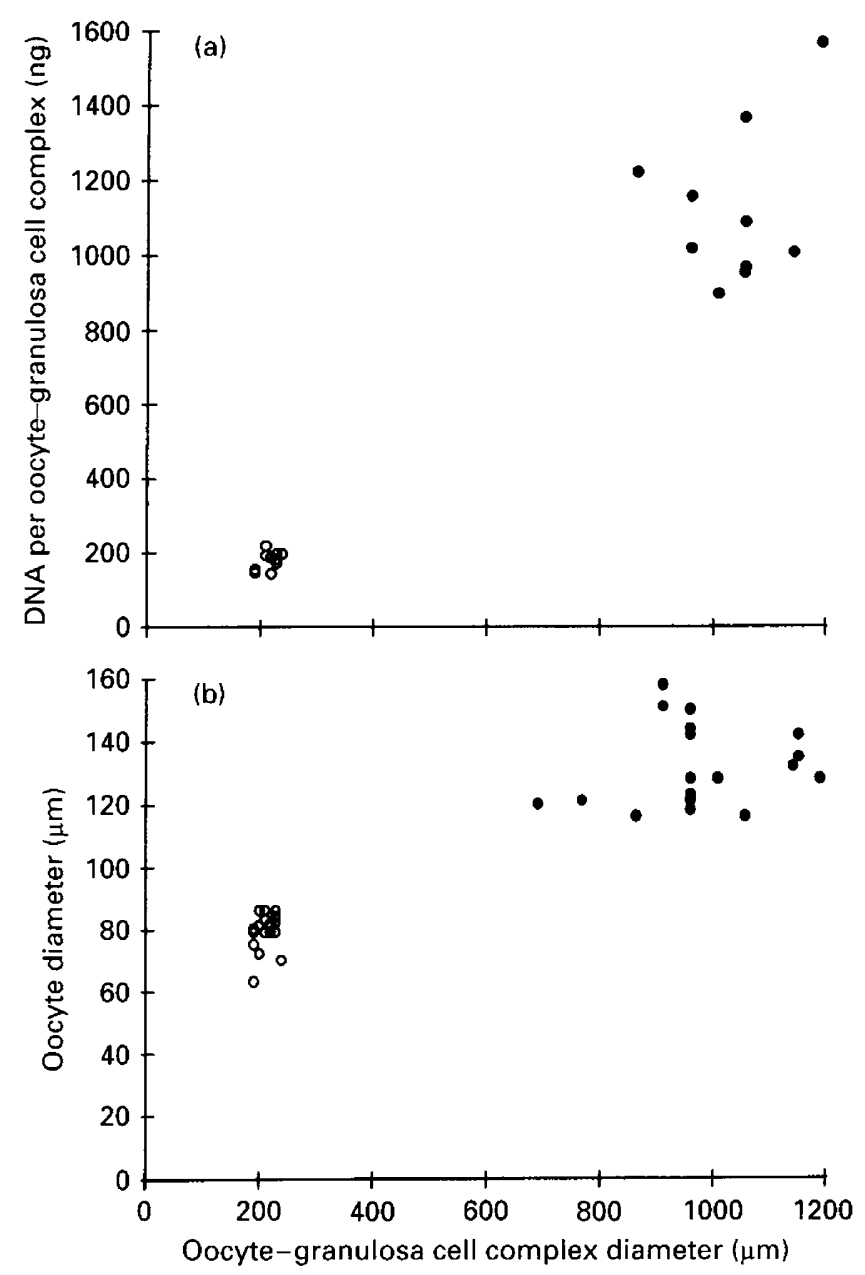

Fig. 4. (a) DNA content (ng per complex) of $(O)$ ovine oocyte-granulosa cell complexes measuring 190-240 $\mu \mathrm{m}$ on the day of isolation and of $(\boldsymbol{\theta})$ complexes that formed antral cavities during 30 days of culture in serum-free medium $(n=10$ per group; $p<0.001)$. (b) Diameter of $(O)$ oocytes within oocyte-granulosa cell complexes isolated from ovine tissue and measured on day 0 and of (-) oocytes within oocyte-granulosa cell complexes that formed antral cavities during 30 days of in vitro culture in serum-free medium $(n=18$ per group; $P<0.001)$.

significantly lower than those cultured with testosterone $(0.11 \pm 0.05 \mathrm{ng}$ per $\mathrm{ml}$ per $48 \mathrm{~h})(P<0.01)$.

Progesterone production did not differ significantly between groups of frozen-thawed and fresh oocytegranulosa cell complexes with antral cavities, or those cultured in different gonadotrophic environments. Therefore, the data were pooled. Progesterone production in spent medium collected on day $2(1.30 \pm 0.35 \mathrm{ng}$ per $\mathrm{ml}$ per $48 \mathrm{~h}$ ) of testosterone stimulation was not significantly different from that collected on day $8(0.89 \pm 0.26 \mathrm{ng}$ per $\mathrm{ml}$ per $48 \mathrm{~h}$ ). Progesterone production in complexes with antral cavities cultured in medium without testosterone did not differ over 8 days of culture and was comparable to that recorded from complexes that received testosterone supplementation $(2.09 \pm 0.24 \mathrm{ng}$ per $\mathrm{ml}$ per $48 \mathrm{~h}$ ).

\section{Discussion}

This is the first study to demonstrate that oocyte-granulosa cell complexes isolated from cryopreserved tissue of a large animal species can grow to $>1 \mathrm{~mm}$ in diameter and form antral cavities in vitro. Furthermore, this can be achieved in a defined serum-free culture system that supports oocyte growth and the induction of the aromatase enzyme complex in follicular granulosa cells.

A number of the oocyte-granulosa cell complexes isolated from frozen-thawed tissue had black necrotic oocytes. In contrast, this phenomenon was rarely seen in those complexes isolated from fresh tissue, which may indicate a detrimental effect of cryopreservation per se. Morphologically normal oocyte-granulosa cell complexes were placed in individual wells for in vitro growth, since a previous study reported that in co-cultures, one follicle is often dominant and limits the growth of the others (Spears et al., 1996). Within $120 \mathrm{~h}$ of culture, approximately $60 \%$ of the oocyte-granulosa cell complexes had extruded their oocytes or lost three-dimensional structure. The cause of this loss is unclear, although damage to the complexes may be caused by two different mechanisms: enzymatic damage or mechanical damage. Increased exposure to collagenase during isolation increased the number of complexes that collapsed due to granulosa cells plating down, resulting in a subsequent loss of structural integrity. These observations suggest that the detrimental effect of collagenase on basement membrane structure is dependent on the duration of digestion. During a short exposure, the damage may be limited and thus a three-dimensional structure is maintained. After extended periods of incubation, the basement membrane may be damaged to such an extent that the support required to maintain spherical structure in vitro is lost, leading to eventual collapse of the oocyte-granulosa cell complex. No similar correlation with duration of collagenase exposure was observed in the proportion of complexes that extruded their oocytes. It is possible that this second effect is a response to localized membrane damage caused by manual dissection. The structure of the oocyte-granulosa complexes remained spherical until oocyte extrusion and only at this point did the integrity of the complex appear to be compromised.

Oocyte-granulosa cell complexes isolated from fresh and frozen-thawed ovine tissue were cultured in serum-free medium with the addition of both FSH and LH since this was considered the most physiological gonadotrophic environment. The numbers that formed antral cavities did not differ significantly between the two groups and ranged from 18 to $25 \%$. This value is lower than that reported in studies of preantral follicles manually isolated from fresh murine tissue in which 40-75\% formed antral cavities (Hartshorne, 1997). However, it is similar to that reported for enzymatically isolated porcine oocyte-granulosa cell complexes (19\%) (Hirao et al., 1994).

Oocyte-granulosa cell complexes harvested from frozenthawed tissue were cultured in medium with different gonadotrophic supplementation. In the presence of FSH and LH or FSH alone, antral formation occurred in $18 \%$ of complexes, but in the absence of gonadotrophin few reached 

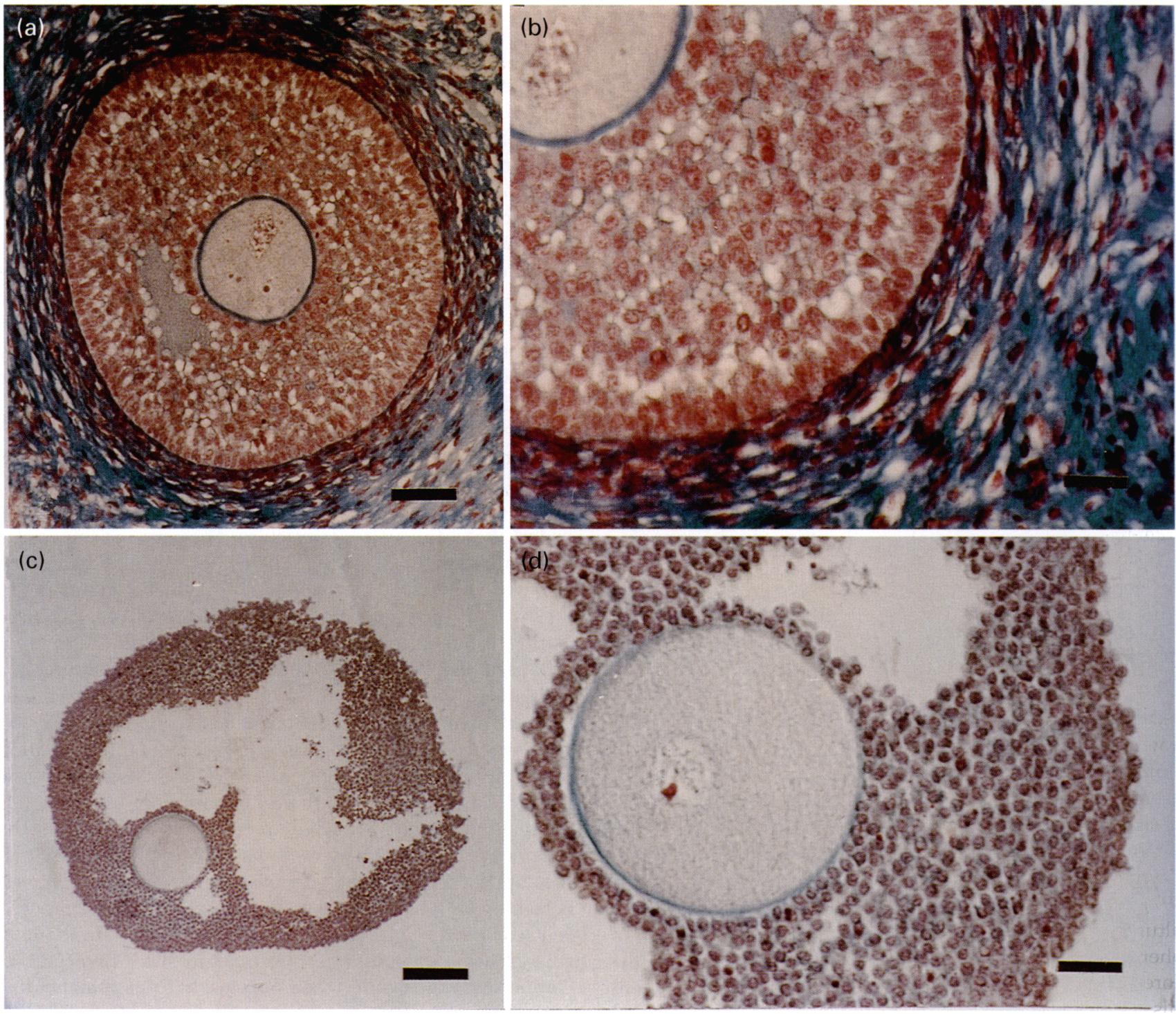

Fig. 5. Histological appearance of ovine antral follicles stained for basement membrane with Azan stain. (a) An antral follicle within a section of frozen-thawed ovine cortical tissue. (b) The follicle in (a) at higher magnification to show intense blue staining in the basement membrane and the zona. (c) An oocyte-granulosa cell complex that formed an antral cavity during 30 days of culture in vitro. (d) High magnification of the complex shown in (c), no basement membrane staining is observed. Scale bars represent (a) $50 \mu \mathrm{m}$, (b) $25 \mu \mathrm{m}$, (c) $100 \mu \mathrm{m}$ and (d) $25 \mu \mathrm{m}$.

the antral stage of development (7\%). These results contradict previous studies in rodents in which antral cavities only developed in the presence of gonadotrophin (Roy and Greenwald, 1989; Cain et al., 1995). One explanation for these findings is that the oocyte-granulosa cell complexes received FSH stimulation in vivo before isolation. Indeed, the presence of FSH in vivo during a critical period of preantral growth may be more important for subsequent development and antral formation than continuous stimulation throughout culture. In support of this hypothesis, work on murine follicles has shown that whilst FSH exposure is important during the first 2 days of culture, normal growth and antral cavity formation occur in the absence of gonadotrophin during the subsequent 3 days (Nayudu and Osborn, 1992). Further evidence is provided by the observation that FSH remains bound to its receptor for 4 days in vivo after gonadotrophic support is removed (Kim and Greenwald, 1986).

Oocyte-granulosa cell complexes that formed antral cavities during culture reached a maximum diameter of approximately $1.1 \mathrm{~mm}$, after which expansion ceased. The normal preovulatory size for this breed in vivo is $4-8 \mathrm{~mm}$. Full expansion may be prevented in vitro if the metabolic requirements of inner cells cannot be met by diffusion. After 30 days of culture, oocytes had reached almost full size (Gosden and Telfer, 1987) and were viable. The nuclear competence of oocytes from complexes cultured with gonadotrophin and testosterone stimulation remains to be tested.

In vivo, the follicle is a highly organized structural unit, 


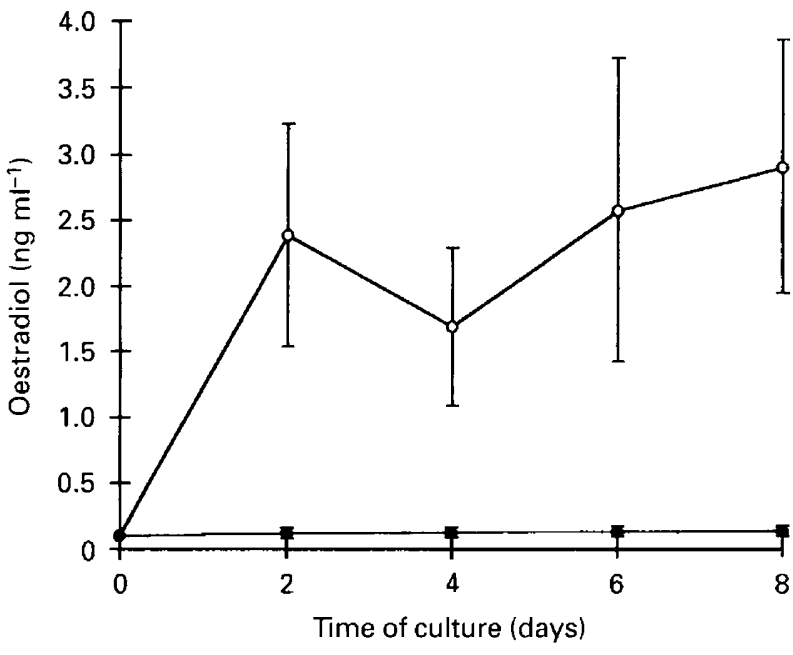

Fig. 6. Oestradiol concentration in culture medium containing oocyte-granulosa cell complexes with antral cavities isolated from fresh and frozen-thawed ovine tissue during 8 days of culture in serum-free medium $(\bigcirc)$ with $(n=12)$ or $(\square)$ without $(n=5)$ stimulation with $100 \mathrm{ng}$ testosterone $\mathrm{ml}^{-1}$. The points represent mean \pm SEM.

consisting of a large population of spherical granulosa cells, a ring of columnar granulosa cells lining the basal lamina and, exterior to this, a thecal layer (Gougeon, 1996). Oocytegranulosa cell complexes grown to antral size in vitro did not show similar morphology; the columnar granulosa cell population and the thecal layer were absent. In addition, the basement membrane appeared to be absent as it was not possible to detect collagen using Azan staining. This phenomenon has been reported in connection with the use of enzymatic follicle isolation (Hirao et al., 1994; Hartshorne, 1997). Despite the loss of these structural components, the cultured oocyte-granulosa cell complexes maintained a spherical shape, although how this was supported is unclear. More extensive histological investigation of the cultured cells, using antibodies to other structural components of the basement membrane, for example laminin, may determine whether these components provided structural support.

Cultured oocyte-granulosa cell complexes that formed an antrum produced oestradiol during 8 days of growth in medium supplemented with testosterone. These results indicate that the aromatase enzyme complex was induced in the actively growing and differentiating small oocytegranulosa cell complexes. The mean amount of oestradiol produced during $48 \mathrm{~h}$ of culture with testosterone was $2.4 \mathrm{ng} \mathrm{ml}^{-1}$, which corresponds to approximately $10 \mathrm{pg}$ per complex per $h$. This value is comparable to that measured in spent medium collected from short term incubations of whole ovine follicles isolated from tissue on day 8 of the luteal phase, which produced $26.2 \pm 4.6$ pg per follicle per $h$ during $2 \mathrm{~h}$ of in vitro incubation (Picton et al., 1990). In the study of Picton et al. (1990), oestradiol production was higher than that measured in the current study because the average follicle diameter was larger $(1.7-2.0 \mathrm{~mm})$. The high oestradiol to low progesterone ratio recorded suggests that the granulosa cells had not luteinized.

In the present study, oocyte-granulosa cell complexes
$<190 \mu \mathrm{m}$ in diameter did not grow to antral size, but either extruded their oocytes or collapsed within $120 \mathrm{~h}$ of the start of culture. This suggests that the system is unsuitable for early stages of preantral development. However, one advantage of the serum-free follicle culture system is that it can be used to investigate factors that are important in follicle growth. This should allow optimization of the culture medium to support the growth of these earlier stages, with the ultimate aim of culturing primordial follicles to maturity, thus maximizing oocyte harvest from frozen-banked tissue. Evidence that primordial follicles can be grown to maturity in vitro has been reported in mice (Eppig and $\mathrm{O}^{\prime}$ Brien, 1996). Using a two-step strategy, primordial follicles were first cultured for 8 days within ovarian stroma as organ explants before the developing oocyte-granulosa cell complexes were isolated and grown to maturity in vitro. The mature oocytes harvested were fertilized and normal embryonic development was recorded, resulting in the production of a viable pup. It is likely that primordial follicles from large animals will also require a multi-step strategy, since stromal factors may influence the earliest stages of development. Primordial follicle growth can be initiated in organ cultures of fetal bovine and primate ovaries, indicating that this strategy may also be successful with human tissue (Wandji et al., 1996, 1997).

The development of an efficient method to preserve, isolate and culture follicles to maturity in vitro would provide an alternative to the current options for fecundity preservation, namely embryo or oocyte freezing. In both humans and large animals, controlled gonadotrophic stimulation of the ovary and follicle aspiration are required to harvest mature oocytes for these procedures. The technique is costly, time consuming and only limited numbers of mature oocytes are collected. In humans, freeze-banking embryos from patients facing gonadotoxic chemotherapy or radiotherapy may preserve fertility potential (Brown et al., 1996), but the creation of frozen embryo banks raises many ethical and legal problems (Trounson and Dawson, 1996). Frozen storage of mature oocytes before insemination is an alternative option but the success rate of this procedure is low (Chen, 1986; Van Uem $e t$ al., 1987; Porcu et al., 1997) and there have been many reports of deleterious changes to the oocyte after thawing (Johnson and Pickering, 1987; Pickering and Johnson, 1987; Van der Elst $e$ t al., 1988; Trounson and Kirby, 1989; Wood et al., 1992). In contrast, the ovarian cortex contains a large supply of primordial and preantral follicles that are small and undifferentiated and thus less likely to be damaged by the freezing process. The cryopreservation of this material should be a more effective method for preserving fecundity and the development of a successful in vitro culture strategy may allow mature oocytes to be harvested efficiently from the immature follicles.

In conclusion, this study has shown that oocyte-granulosa cell complexes isolated from the frozen-thawed tissue of large animals can be grown to antral size in vitro. The technique has many applications. As a research tool, the model facilitates the study of factors that are important during in vitro growth of follicles, and may also prove a useful method for the introduction of foreign DNA into the 
germ line. The freeze--banking of tissue from fertile donors or recently deceased animals of rare breeds, endangered species or transgenic animals may facilitate the harvest of immature follicles and hence mature oocytes from these precious animals. This is particularly important for endangered species whose populations are often maintained by captive breeding programmes in which the small number of animals may lead to inbreeding depression. The periodic release of banked oocytes into these groups may help to increase the genetic diversity and maintain species fitness in rapidly dwindling populations (Ballou, 1992). From a clinical viewpoint, the technology may also prove important for harvesting the reproductive potential from the frozenbanked tissue of cancer patients sterilized by chemotherapy or radiotherapy. Although follicle culture technology is still in its infancy, the rapidly expanding knowledge in the field of reproductive biology may allow the use of these techniques for assisted reproduction in the future.

The authors thank the Leukaemia Research Fund and the Royal Society for generously supporting this work. They also wish to thank the National Institute of Arthritis, Diabetes and Digestive and Kidney Diseases (NIADDK), California, for their generous donation of FSH and LH preparations.

\section{References}

Abir R, Franks S, Mobberley MA, Moore PA, Margara RA and Winston RM (1997) Mechanical isolation and in vitro growth of preantral and small antral human follicles Fertility and Sterility 68 682-688

Ballou JD (1992) Potential contribution of cryopreserved germ plasm to the preservation of genetic diversity and conservation of endangered species in captivity Cryobiology 29 19-25

Brown JR, Modell E, Obasaju M and King YK (1996) Natural cycle in vitro fertilisation with embryo cryopreservation prior to chemotherapy for carcinoma of the breast Human Reproduction 11 197-199

Cain L, Chatterjee S and Collings TJ (1995) In vitro folliculogenesis of rat preantral follicles Journal of Endocrinology 136 3369-3377

Campbell BK, Scaramuzzi RJ and Webb R (1996) Induction and maintenance of estradiol and immunoreactive inhibin production with FSH by ovine granulosa cells cultured in serum-free media Journal of Reproduction and Fertility $1067-16$

Chen C (1986) Pregnancy after human oocyte cryopreservation Lancet 1 884-886

Cortvrindt R, Smitz J and Van Steirteghem AC (1996a) In-vitro maturation, fertilisation and embryo development of immature oocytes from early preantral follicles from prepubertal mice in a simplified culture system Hunan Reproduction 11 2656-2666

Cortvrindt R, Smitz J and Van Steirteghem AC (1996b) A morphological and functional study of the effect of slow freezing followed by complete in-vitro maturation of primary mouse ovarian follicles Human Reproduction 11 2648-2655

Culling CFA (1974) Handbook of Histopathological and Histochemical Techniques 3rd Edn p 416 Butterworths, London

Eppig JJ and O'Brien MJ (1996) Development in vitro of mouse oocytes from primordial follicles Biology of Reproduction 54 197-207

Gosden RG and Telfer E (1987) Scaling of follicular sizes in mammalian ovaries Journal of Zoology 211 157-168

Gosden RG, Boland NI, Spears N, Murray AA, Chapman M, Wade JC, Zohdy NI and Brown N (1993) The biology and technology of follicular oocyte development in vitro. Reproductive Medicine Review 2 129-152

Gosden RG, Baird DT, Wade JC and Webb R (1994) Restoration of fertility to oophorectomised sheep by ovarian autografts stored at $-196^{\circ} \mathrm{C}$ Human Reproduction 9 597-603

Gougeon A (1996) Regulation of ovarian follicular development in primates: facts and hypotheses Endocrine Reviews 17 121-155
Hartshorne GM (1997) In vitro culture of ovarian follicles Reviews of Reproduction 294-104

Hirao Y, Nagai T, Kubo M, Miyano T, Miyake M and Kato S (1994) In vitro growth and maturation of pig oocytes fournal of Reproduction and Fertility $100333-339$

Hovatta O, Silye R, Krausz T, Abir R, Margara R, Trew G, Lass A and Winston RM (1996) Cryopreservation of human ovarian tissue using dimethylsulphoxide and propanediol-sucrose as cryoprotectants Human Reproduction 11 1268-1272

Johnson MH and Pickering SJ (1987) The effect of dimethylsulphoxide on the microtubular system of the mouse oocyte Development 100 313-324

Kim I and Greenwald GS (1986) Occupied and unoccupied FSH receptors in follicles of cyclic, hypophysectomised or hypophysectomisedgonadotrophin treated hamsters Molecular and Cellular Endocrinology $\mathbf{4 4}$ 141-145

Li RH, Phillips DM and Mather JP (1995) Activin promotes ovarian follicle development in vitro. Journal of Endocrinology 136 849-856

Nayudu PL and Osborn SM (1992) Factors influencing the rate of preantral and antral growth of mouse ovarian follicles in vitro. Journal of Reproduction and Fertility 95 349-362

Newton H, Aubard Y, Rutherford A, Sharma V and Gosden RG (1996) Low temperature storage and grafting of human ovarian tissue Human Reproduction 11 1487-1491

Oktay K, Nugent D, Newton H, Salha O and Gosden RG (1997) Isolation and characterisation of primordial follicles from fresh and cryopreserved human ovarian tissue Fertility and Sterility 67 481-486

Oktay K, Newton H, Aubard Y, Salha O and Gosden RG (1998) Cryopreservation of immature human oocytes and ovarian tissue - an emerging technology? Fertility and Sterility 69 1-7

Pickering SJ and Johnson MH (1987) The influence of cooling on the organisation of the meiotic spindle of the mouse oocyte Human Reproduction $2207-216$

Picton HM, Tsonis CG and McNeilly AS (1990) FSH causes a time-dependent stimulation of preovulatory follicle growth in the absence of pulsatile $\mathrm{LH}$ secretion in ewes chronically treated with gonadotrophin-releasing hormone agonist journal of Endocrinology 126 297-307

Porcu E, Fabbri R, Seracchioli R, Ciotti PM, Magrini O, Savelli L and Flamigni C (1997) Birth of a healthy female after intracytoplasmic sperm injection of cryopreserved human oocytes Fertility and Sterility 68 724-726

Qvist R, Blackwell LF, Bourne H and Brown JB (1990) Development of mouse ovarian follicles from primary to preovulatory stages in vitro. Journal of Reproduction and Fertility 89 169-180

Roy SK and Greenwald GS (1989) Hormonal requirements for the growth and differentiation of hamster preantral follicles in long-term culture Journal of Reproduction and Fertility 87 103-114

Roy SK and Treacy BJ (1993) Isolation and long-term culture of human preantral follicles Fertility and Sterility 59 783-790

Spears N, Boland NI, Murray AA and Gosden RG (1994) Mouse oocytes derived from in vitro grown primary ovarian follicles are fertile Human Reproduction 9 527-532

Spears N, deBruin JP and Gosden RG (1996) The establishment of follicular dominance in co-cultured mouse ovarian follicles Journal of Reproduction and Fertility $1061-6$

Trounson A and Dawson K (1996) Storage and disposal of embryos and gametes British Medical Journal 313 1-2

Trounson A and Kirby C (1989) Problems in the cryopreservation of unfertilised eggs by slow cooling in dimethyl sulfoxide Fertility and Sterility 52 778-786

Van der Elst J, Van den Abbeel E, Jacobs R, Wisse E and Van Steirteghem A (1988) Effect of 1,2-propanediol and dimethylsulphoxide on the meiotic spindle of the mouse oocyte Human Reproduction 3 960-967

Van Uem JF, Siebzehnrubl ER, Schuh B, Koch R, Trotnow S and Lang N (1987) Birth after cryopreservation of unfertilised oocytes Lancet 1 752-753

Wandji SA, Srsen V, Voss AK, Eppig JJ and Fortune JE (1996) Initiation in vitro of growth of bovine primordial follicles Biology of Reproduction $\mathbf{5 5}$ 942-948

Wandji SA, Srsen V, Nathanielsz PW, Eppig JJ and Fortune JE (1997) Initiation of growth of baboon primordial follicles in vitro. Human Reproduction 12 1993-2001

Wood MJ, Whittingham DG and Lee SH (1992) Fertilization failure of frozen mouse oocytes is not due to premature cortical granule release Biology of Reproduction 46 1187-1195 